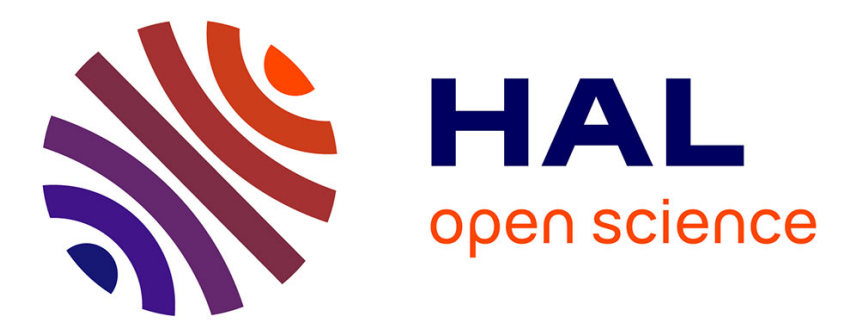

\title{
Sequential regulation of ferroportin expression after erythrophagocytosis in murine macrophages: early mRNA induction by heme followed by iron-dependent protein expression
}

Constance Delaby, Nathalie Pilard, Hervé Puy, François Canonne-Hergaux, François Canonne-Hergaux

\section{To cite this version:}

Constance Delaby, Nathalie Pilard, Hervé Puy, François Canonne-Hergaux, François CanonneHergaux. Sequential regulation of ferroportin expression after erythrophagocytosis in murine macrophages: early mRNA induction by heme followed by iron-dependent protein expression. Biochemical Journal, 2008, 411 (1), pp.123-131. 10.1042/BJ20071474 . hal-00478904

\author{
HAL Id: hal-00478904 \\ https://hal.science/hal-00478904
}

Submitted on 30 Apr 2010

HAL is a multi-disciplinary open access archive for the deposit and dissemination of scientific research documents, whether they are published or not. The documents may come from teaching and research institutions in France or abroad, or from public or private research centers.
L'archive ouverte pluridisciplinaire HAL, est destinée au dépôt et à la diffusion de documents scientifiques de niveau recherche, publiés ou non, émanant des établissements d'enseignement et de recherche français ou étrangers, des laboratoires publics ou privés. 
Sequential regulation of ferroportin expression after erythrophagocytosis in murine macrophages: early mRNA induction by heme followed by iron-dependent protein expression.

\section{Constance Delaby ${ }^{1,2}$, Nathalie Pilard ${ }^{1}$, Hervé Puy ${ }^{1,2}$ and François Canonne-Hergaux ${ }^{3}$}

From INSERM U773, Centre de Recherche Biomédicale Bichat Beaujon CRB3; Université Denis Diderot, site Bichat, Paris France ${ }^{1}$, AP-HP, Centre Français des Porphyries, Hôpital Louis Mourier, Colombes, France ${ }^{2}$, UPR 2301, CNRS, Institut de Chimie des Substances Naturelles, Gif-Sur-Yvette, France ${ }^{3}$.

Address correspondence to: Canonne-Hergaux François, $\mathrm{PhD}$, Chargé de Recherche INSERM, UPR2301, CNRS, Institut de Chimie des Substances Naturelles (ICSN), Equipe 34, Bâtiment 27, Avenue de la Terrasse, 91198 Gif-sur-Yvette Cedex France ; Phone: (33) 169 823081 ; Fax: (33) 169077247 ; E-mail: fcanonne@icsn.cnrs-gif.fr

Short title: Distinct heme and iron regulation of ferroportin expression. 


\section{SYNOPSIS}

Tissue macrophages play an essential role in iron recycling through the phagocytosis of senescent erythrocytes. Following heme catabolism by heme oxygenase1 (HO1), they recycle iron back into the plasma through the iron exporter ferroportin (Fpn). We previously described a cellular model of erythrophagocytosis (EP), based on primary cultures of mouse bone-marrow derived macrophages (BMDM) and aged murine erythrocytes, and showed that EP induces changes in the expression profiles of Fpn and HO1. In the present paper, we demonstrate that heme derived from human or murine RBC or from an exogenous source of heme led to marked transcriptional activation of the Fpn and HO1 genes. Iron released from heme catabolism subsequently stimulated the Fpn mRNA and protein expression associated with localisation of the transporter at the cell surface, which probably promotes the export of iron into the plasma. These findings highlight a dual mechanism of Fpn regulation in BMDM, characterized by early induction of the gene transcription predominantly mediated by heme, followed by iron-mediated, post-transcriptional regulation of the exporter.

Keywords : ferroportin, heme oxygenase, transcriptional and post-transcriptional regulation, erythrophagocytosis, heme, Iron. 


\section{INTRODUCTION}

Most of the iron in the body is associated with the hemoglobin of circulating red blood cells (RBC). Phagocytosis of senescent erythrocytes by tissue macrophages (namely erythrophagocytosis, EP) ensures the efficient recycling of iron, and provides the bone marrow with the iron required for erythropoiesis [1]. EP takes place mainly in the spleen, the bone marrow macrophages, and the Küpffer cells of the liver. After being recognized and bound to the macrophage, the erythrocyte is engulfed in a phagosome, and the subsequent maturation of the phagosome leads to degradation of the erythrocytic hemoglobin and the catabolism of heme. This latter process leads to the release of iron, $\mathrm{CO}$ and bilirubin, through the action of an enzymatic complex containing an NADPH-cytochrome c reductase, heme oxygenase 1 (HO1) and biliverdin reductase. HO1 is the rate-limiting enzyme of heme catabolism in macrophage cells [2-4]. Following its release from heme, iron may be stored in macrophages associated with ferritin molecules, or exported back into the plasma to meet the body's iron needs [5]. The egress of iron from the macrophages is controled by ferroportin (Fpn) [6-9], the sole iron exporter to have been identified in mammals.

Fpn is a major player in iron homeostasis, and the regulation of its expression is complex and has been shown to rely on transcriptional, post-transcriptional and posttranslational mechanisms in response to various stimuli in different cell types. At the protein level, two distinct mechanisms have been extensively described in recent years. First of all, iron was shown to play a key role in Fpn protein expression. Like ferritin messengers, Fpn mRNAs present an iron responsive element (IRE) motif in the 5' untranslated region (UTR) $[7,8]$. In the absence of iron, the binding of iron regulatory protein 1 or 2 (IRP 1 or IRP2) to 5'IRE inhibits the translation of mRNAs [10]. In contrast, the entry of iron into cell induces a change in IRP1 conformation (by acquisition of an iron-sulfur cluster), oxidation of IRP2 (followed by its degradation in the proteasome), and leads to the translation of 5'IRE containing mRNAs [10]. The IRE present in Fpn mRNAs has been shown to be functional in various cell types, including the human monocytic cell line U937 [11], and the mouse macrophage cell line RAW264.7 [12]. Fpn protein expression in macrophages is dramatically increased by iron [13, 14]. Iron mediated overexpression of Fpn is also associated with an increased level of the iron exporter at the cell surface [13]. In addition to this posttranscriptional positive regulation, a negative regulatory mechanism of Fpn protein expression was revealed by the discovery of hepcidin, the major regulator of iron homeostasis [15-17]. Hepcidin is a small, 25-aminoacid peptide produced mainly by the liver. Hepcidin has been shown to bind to Fpn in epithelial cells [18], and to induce the internalization and subsequent 
degradation of the exporter in the lysosomal compartment both in these cells $[18,19]$ and in primary mouse macrophages [13, 20].

Unlike Fpn regulation at the protein level by intracellular (iron) or systemic (hepcidin) regulators, the mechanisms involved in the transcriptional regulation of Fpn gene remain to be elucidated. In cultured primary macrophages, activation by lipopolysaccharides (LPS) and Interferon gamma (IFN $\gamma$ ) leads to a marked decrease in the Fpn messenger [21]. Fpn mRNAs also increase in freshly isolated human alveolar macrophages exposed for 24 hours to ferric ammonium citrate [22], as well as in murine J774 macrophages loaded for 20 hours with FeNTA [14]. We [21] and others [14] have shown that the exporter mRNAs are increased during the first few hours of EP in various sources of macrophages.

The purpose of the present work was to investigate the molecular mechanisms involved in Fpn gene regulation during the first few hours of EP in bone marrow derived macrophages (BMDM).

\section{EXPERIMENTAL PROCEDURES}

Cell Culture - Bone marrow derived macrophages (BMDM) were cultured as previously described [21]. Briefly, bone marrow cells were isolated from femurs of 6- to 8- week-old mice (DBA/2 strain), and seeded onto 6- or 10-cm diameter petri dishes for RNA or protein extraction respectively, or onto glass coverslips in 24-well tissue culture plates for immunofluorescence studies. The culture medium was RPMI-glutamax (Invitrogen, Cergy Pontoise, France) supplemented with 10\% heat-inactivated fetal calf serum (FCS, Invitrogen, low endotoxin content), 10\% L929-cell-conditioned medium (source of CSF-1), 2 mM Lglutamine, $50 \mathrm{U} / \mathrm{mL}$ penicillin, and $50 \mathrm{mg} / \mathrm{mL}$ streptomycin. Four days after seeding, the adherent cells were rinsed twice with Hank's balanced salt solution (HBSS), and the medium was changed daily until day 7 .

Special reagents - Tin-protoporphyrin (SnPPIX) was obtained from Porphyrin Products (Frontier Scientific, London, UK), hemin and protoporphyrin IX (PPIX) was from SigmaAldrich (Saint Quentin Fallavier, France). Freshly prepared $1 \mathrm{mM}$ stock solutions of porphyrins with $10 \mathrm{mM}$ arginine were made by dilution in $0.2 \mathrm{~N} \mathrm{KOH} / 100 \%$ ethanol $(1: 1$, v/v). Normosang ${ }^{\circledR}$ (NS; human hemin, Orphan Europe, Paris, France) was obtained from the Centre Français des Porphyries, Hôpital Louis Mourier, Colombes, France.

Erythrophagocytosis assay - Mouse and human blood samples (obtained by retro-orbital puncture and intravenous sampling respectively) were collected in heparin pre-coated tubes, and washed with Phosphate Buffer Saline (PBS). The RBC were then artificially aged by 
incubating with $2.5 \mathrm{mM}$ calcium and 0.125 to $0.5 \mu \mathrm{M} \mathrm{Ca} 2+$ ionophore A23187 (Calbiochem, La Jolla, CA, USA) as previously described [21]. BMDM were incubated with aged RBC (1 to $3 \times 10^{7}$ cells $/ \mathrm{ml} ; 1 \mathrm{ml} /$ well in 24 well-plates, $5 \mathrm{ml}$ in $60-\mathrm{mm}$ or $10 \mathrm{ml}$ in $100-\mathrm{mm}$ petri dishes) for 1 hour at $37^{\circ} \mathrm{C}$ in a $5 \% \mathrm{CO} 2$ incubator, and then washed twice with HBSS. Cells were then incubated for $5 \mathrm{~min}$ in hypotonic solution (140 mM NH4Cl, $17 \mathrm{mM}$ Tris- $\mathrm{HCl} \mathrm{pH} 7.6)$ to lyse any non-ingested RBC, and fresh medium was added after specified periods of time.

Cell treatments - Macrophages were incubated with heme- or PPIX-arginate at a final concentration of $10 \mu \mathrm{M}$ for 2 hours. The medium was then discarded, the BMDM were washed twice with PBS, and fresh medium was added for 2 or 6 hours before RNA extraction or immunofluorescence study, respectively. For the treatment with NS, the cells were incubated with this reagent for the periods of time indicated ( 4 or 8 hours). To block HO1 activity, BMDM were pre-treated with $50 \mu \mathrm{M}$ SnPPIX for 2 hours, before adding $10 \mu \mathrm{M}$ NS for 2 or 6 hours before RNA or protein extraction, respectively. We have previously shown that H-ferritin protein levels increased with Fe-NTA reflecting increased intracellular iron concentrations [13]. Therefore to increase the cellular iron concentration, cells were incubated with Fe-NTA $(100 \mu \mathrm{M} \mathrm{FeCl3}-400 \mu \mathrm{M}$ NTA), for the indicated periods of time (4 or 8 hours). To chelate iron from the cells, BMDM were incubated with salicylaldehyde isonicotinoyl hydrazone ( $\mathrm{SIH})$. SIH was prepared as a $100 \mathrm{mM}$ stock solution in dimethyl sulfoxide (DMSO; Sigma Aldrich), and used at a final concentration of 10 to $50 \mu \mathrm{M}$. DMSO or $0.2 \mathrm{~N} \mathrm{KOH} / 100 \%$ ethanol was used as controls for the studies with $\mathrm{SIH}$ or porphyrins, respectively. For the studies using NS, a solution corresponding to the excipient was used as a control. To block transcription, cells were treated with actinomycin D $(1 \mu \mathrm{g} / \mathrm{mL}$; SigmaAldrich), in the presence or absence of either RBC or NS. Cell viability was assessed using the Guava Count technology according to the manufacturer's instructions, and was shown to be $>95 \%$ for all the treatments used.

Determination of intracellular heme content - After incubating the macrophages with RBC or NS for 50 or 90 minutes respectively, the intracellular heme content was determined according to the method of Motterlini et al. [23]. Briefly, cells were washed with PBS, centrifuged, and the pellet was then solubilized by adding $500 \mu 1$ of concentrated formic acid. The heme concentration of the formic acid solution was determined spectrophotometrically at $400 \mathrm{~nm}$.

Real time quantitative PCR analysis - Total RNA was extracted from cells using the RNeasy Mini Kit (Qiagen, Courtaboeuf, France) according to the manufacturer's instructions. Single strand cDNA was synthesized using SuperScriptTM Rnase H- Reverse Transcriptase 
(Invitrogen). Real time quantification of transcripts was performed in $20 \mu \mathrm{L}$ in CHROMO IV Detector (MJ Research, Boston MA) using SYBR Green PCR master mix (Sigma SYBR Green JumpStartTM Taq ReadyMixTM for quantitative PCR), $10 \mathrm{pmol}$ of forward and reverse primers, and $5 \mu \mathrm{L}$ of reverse transcriptase reaction mixture. Sequences of the primers for Fpn, HO1 and S14 were as previously described [21]. The analyses were performed using the Opticon Monitor software version 2.03 (MJ Research). Amplification and dissociation curves of increasing amounts of BMDM cDNA were used to validate our assay: the dissociation curves displayed a single peak, ruling out the possibility of the presence of primer dimers or parasitic products. The results for each gene were normalized using the $\mathrm{Ct}$ value of $\mathrm{S} 14$ ribosomal protein. The relative quantification was calculated using a comparative $\mathrm{Ct}$ method with the following arithmetic formula: $\left(1+\mathrm{E}_{\mathrm{X}}\right)-\Delta \mathrm{Ct}_{\mathrm{X}} /\left(1+\mathrm{E}_{\mathrm{S1} 14}\right)-\Delta \mathrm{Ct}_{\mathrm{S} 14}$, were $\mathrm{E}_{\mathrm{X}}$ is the efficiency of amplification of the gene of interest, $E_{S 14}$ the efficiency of amplification of the S14 target, and $\Delta \mathrm{CT}=$ mean $\mathrm{Ct}$ stimulated condition - mean $\mathrm{Ct}$ control condition. The standard deviation of the difference was calculated from the standard deviations of each gene (s1), and S14 (s2) values using the following formula: $\mathrm{s}=\sqrt{ }\left(\mathrm{s} 1^{2}+\mathrm{s} 2^{2}\right)$. In the figures, the results are the median values of data obtained for 3 to 6 independent experiments, and error bars represent the standard deviation.

Statistical analysis - Statistical significance was evaluated using the non-parametric KruskalWallis test (to compare two, three or more unpaired groups) and the Mann-Whitney test (to compare the medians of two unpaired groups). GraphPad Prism software (GraphPad Software, San Diego, CA) was used for statistical evaluation.

Antibodies - The specificity of the rabbit polyclonal anti-mouse Fpn antibody has already been described [24, 25]. Rabbit polyclonal anti-mouse HO1 was purchased from Stressgen Biotechnologies (Canada). Rabbit polyclonal anti-mouse H-ferritin antibody was a kind gift from P. Santambrogio and S. Levi (DIBIT San Raffaele Scientific Institute, Milano, Italy). The mouse monoclonal anti- $\beta$ actin was purchased from Sigma-Aldrich.

Protein extracts from macrophage cell cultures - Protein extracts from BMDM were prepared as previously described [13]. Briefly, cells were washed with cold PBS, scraped into PBSEDTA (ethylene-diaminetetraacetic acid, $2 \mathrm{mM}$ ), and centrifuged at $1500 \mathrm{rpm}$ for $5 \mathrm{~min}$. The cell pellets were then homogenized in $150 \mu \mathrm{l}$ of lysis buffer $(10 \mathrm{mM}$ Tris- $\mathrm{HCl}, \mathrm{pH} 7 ; 1 \mathrm{mM}$ $\mathrm{MgC1}$ ) supplemented with protease inhibitor cocktail EDTA free (PIs, Roche Diagnostics, Meylan, France). The lysate was centrifuged at $3500 \mathrm{rpm}$ for $10 \mathrm{~min}$, to eliminate nuclei and unbroken cells. The protein extracts were then ultracentrifuged at 200,000 g (TLA100, Beckman; 75,000 rpm) to separate the crude membrane fractions from the cytosolic proteins. 
Supernatants corresponding to cytosolic extracts were then collected and membrane pellets were resuspended in TNE buffer (100 mM NaCl; $10 \mathrm{mM}$ Tris-HCl, $\mathrm{pH} 7.0 ; 10 \mathrm{mM}$ EDTA) containing 30\% glycerol and PIs. All protein extracts (fom PNS, membrane or cytosolic fractions) were stored at $-80^{\circ} \mathrm{C}$ until use. The protein concentrations of all the samples were determined by the Bradford assay (Biorad, Marne la Coquette, France).

Western-blot analysis - $10 \mu \mathrm{g}$ of crude membrane proteins solubilized in 1X Laemmli buffer were incubated for $30 \mathrm{~min}$ at room temperature (RT) for HO1 and Fpn detections. $10 \mu \mathrm{g}$ of cytosolic proteins were boiled for $5 \mathrm{~min}$ at $90^{\circ} \mathrm{C}$ for $\mathrm{H}$-ferritin detections. Samples were then analyzed by SDS-PAGE electrophoresis and electro-transfer ( $2 \mathrm{~h}$ at $110 \mathrm{~mA}$; Novex Western transfer apparatus, Invitrogen) on a polyvinylidene fluoride (PVDF) membrane. To control for loading and transfer, the membranes were stained with Ponceau red after transfer, and subsequently preincubated with blocking solution [7\% skim milk in TBST $(0.15 \%$ Tween 20 , in Tris buffered saline) for Fpn, HO1 and H-Ft, or 1\% BSA in TBST for $\beta$-actin] for $1 \mathrm{~h}$ at RT. The membranes were then incubated with primary antibodies as follows: anti-Fpn: 1/300 (16 hours at $4^{\circ} \mathrm{C}$ ); anti-HO1:1/10000, anti-H-Ft:1/1000 (1 hour at RT); anti $\beta$-actin:1/5000 (30 min at RT). After washing with TBS-T, the blots were incubated with donkey peroxidaselabeled anti-rabbit immunoglobulin (1/3000, Nordic Immunologic, Tebubio, le Perray en Yvelines, France) for $1 \mathrm{~h}$ at $\mathrm{RT}$, or sheep peroxydase-labeled anti-mouse immuno-globulin (1/5000, Amersham, GE Healthcare, Orsay, France) for $30 \mathrm{~min}$ at RT and revealed by Enhanced ChemiLuminescence (ECL Amersham, GE Healthcare).

Immunofluorescence analysis - The cells were fixed with $100 \%$ methanol at $-20^{\circ} \mathrm{C}$ for 15 min, washed with PBS and then permeabilized with Triton X100 (0.1\% in PBS) for $10 \mathrm{~min}$. After two PBS washes, the cells were incubated in a blocking solution (BSA $1 \%$ and $10 \%$ heat inactivated goat serum in PBS) for $45 \mathrm{~min}$ at room temperature. They were then incubated with primary rabbit anti-Fpn antibodies in a humid chamber at room temperature for $1 \mathrm{~h}$ using a 1/50 dilution in blocking solution. After 3 washes with PBS/0.5\% BSA, cells were incubated for $1 \mathrm{~h}$ at RT with Alexa 488-conjugated goat anti-rabbit (MolecularProbes, Invitrogen) diluted at $1 / 200$ in blocking solution. Slide coverslips were then washed $3 \mathrm{X}$ in PBS $/ 0.5 \%$ BSA, $1 \mathrm{X}$ in PBS, mounted with antifading mounting reagent (Prolong Antifade kit P-7481 MolecularProbes, Invitrogen), and processed for immunofluorescence. Cells were visualized using an epifluorescence microscope LEICA DM-IRM with a 100X oil immersion objective. Images were acquired using either ARCHIMED-PRO (Microvision Instrument). 


\section{RESULTS}

Ferroportin and HOI mRNA induction after erythrophagocytosis of human red blood cells by BMDM.

Using murine red blood cells, we have previously shown that Fpn and HO1 mRNAs are maximally induced after 4 hours of EP in BMDM [21]. Here, we performed similar experiments using human red blood cells (hRBC) treated with the calcium ionophore A23187 and calcium in order to mimic eryptosis, the process of RBC aging [26]. After EP, the expression of Fpn and HO1 was followed by quantitative RT-PCR (Figure 1A). Using different concentrations of artificially aged $\mathrm{hRBC}$, we reproduced our previous observations [21], and then extended them by showing that both HO1 and Fpn mRNA expression increase in parallel to the number of hRBC used in our EP assay. To find out whether these mRNA changes depended on iron release during EP, we performed the EP assay and subsequent kinetics in the presence of the rapidly permeant iron chelator SIH (Figure 1B). SIH had no effect on HO1 mRNA, and produced modest but not significant inhibition of Fpn induction.

Early increase in Fpn and HO1 mRNA levels in the presence of heme in BMDM.

Heme is known to enhance HOl-gene transcription in various cell types including macrophages [27]. We therefore wondered if heme itself, released following the degradation of $\mathrm{RBC}$, could be directly involved in regulating the expression of $\mathrm{HO} 1$ and Fpn during EP. To test this hypothesis, we first evaluated the rate of heme catabolism following EP in BMDM (Figure 2). For this purpose, BMDM were incubated with the same number of artificially aged murine (Figure 2A) or human (Figure 2B) RBC for 50 minutes to induce EP. The intracellular heme content over time after EP displayed a similar kinetic profile for both types of RBC, with an increase during the first 30 minutes following EP and a progressive decrease thereafter (Figure 2).

We then studied the effect of different source of heme (Normosang® NS; heme arginate) on the level of Fpn and HO1 mRNAs (Figure 3). NS treatment induced a rapid and marked accumulation of intracellular heme (increased more than 30 fold in response to the 50- $\mu \mathrm{M}$ concentration) (Figure 3A). Interestingly, Fpn and HO1 mRNA were also markedly increased by NS in a dose-dependent manner (Figure $3 \mathrm{~A}$ and supplemental data 1). Furthermore, incubating BMDM with protoporphyrin IX (PPIX)-arginate, an iron-free heme precursor, did not significantly increase the level of Fpn and HO1 mRNAs when compared to incubating with the same dose of heme-arginate (Figure 3B). This observation clearly 
indicates the importance of the iron atom present in the protoporphyrin ring in Fpn and HO1 mRNA mediated induction.

Effect of iron chelation in the induction of Fpn and HOI mRNAs and proteins by heme in BMDM.

To discriminate between the respective roles of heme and of iron released from NS, we carried out NS treatment in the presence of SIH (Figure 4A). Results showed that induction of HO1 mRNAs after 4 hours of NS was not significantly modified by iron chelation. On the other hand, the induction of Fpn by NS was modestly but significantly blocked by SIH (Figure 4A).

Fpn, HOl, and H-ferritin proteins are indirectly induced by heme in BMDM.

We then tested whether induction of Fpn mRNA by a source of heme is associated with increased protein synthesis. BMDM were treated with NS, heme arginate, or PPIX-arginate, and then processed for immunofluorescence (Figure 4B). As a positive control, macrophages were treated with Fe-NTA that was previously shown to increase Fpn expression [13]. We observed that, like Fe-NTA, both NS and heme-arginate dramatically increased the protein expression of the transporter relative to untreated cells. The iron in heme was strictly necessary for this induction, since PPIX-arginate did not induce any change in Fpn expression. As observed with Fe-NTA, Fpn induced by heme strongly localized to the plasma membrane of macrophages (Figure 4B). We next evaluated the effect of the iron chelator SIH on the induction of Fpn and HO1 proteins by Western blotting after exposure of NS for 8 hours (Figure 4C). As a control of intracellular iron changes, H-ferritin expression was also studied. NS strongly induced the expression of Fpn, HO1 and H-Ft proteins. Interestingly, the induction of both Fpn and $\mathrm{H}$-ft by NS (Figure 4C) was markedly inhibited in the presence of $\mathrm{SIH}$. In contrast, induction of the $\mathrm{HO} 1$ protein by NS was not affected by iron chelation. Similar observations were made after 8 hours of EP (Supplemental data 2).

\section{Transcriptional regulation of Fpn by heme.}

The effect of heme on Fpn and HO1 mRNA levels could reflect induction of transcription of these genes or stabilization of pre-existing mRNAs. To clarify this point, BMDM stimulated with NS for 4 hours were incubated with the transcriptional inhibitor actinomycin D for the same period of time (Figure 5A). Interestingly, the induction of Fpn and HO1 mRNAs by NS was inhibited in the presence of actinomycin D, supporting the 
hypothesis that the positive effect of heme on these two genes in BMDM involves transcriptional activation. Accordingly, by blocking transcription, actinomycin D also prevented the NS-induced synthesis of Fpn and HO1 proteins (Figure 5B). On the other hand, actinomycin D had only a limited effect on the induction of H-Ft by NS, confirming a strong effect of a post-transcriptional mechanism (iron dependent) in the regulation of this gene.

HO1-dependent release of iron from heme causes induction of the Fpn protein in BMDM.

Our previous findings (Figure 4) suggest that iron released from heme after EP or NS treatment is responsible for inducing Fpn and H-ferritin proteins. HO1 is the enzyme responsible for catabolising heme and releasing iron in phagocytic cells [3]. We therefore investigated whether this enzyme was necessary for the Fpn and H-ferritin proteins to be induced by NS in BMDM (Figure 6). To do this, cells were pre-incubated for 2 hours with an inhibitor of HO1 activity, namely tin-protoporphyrin IX (SnPPIX) before being exposed to

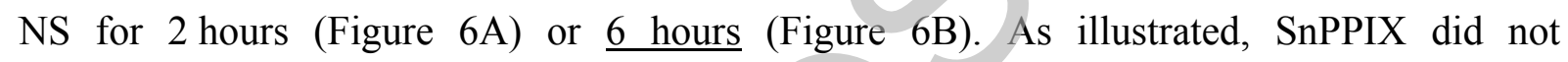
significantly modify the high level of Fpn or HO1 mRNAs induced by NS (Figure 6A), indicating that inhibiting heme degradation does not affect the induction of either of genes by NS (Figure 6A). In addition, the Fpn mRNAs are not sensitive to SIH when heme degradation is inhibited by SnPPIX, supporting the hypothesis that transcriptional regulation of Fpn is predominantly regulated by heme, and only slightly by iron. At the protein level, SnPPIX only partially prevented the accumulation of $\mathrm{HO} 1$ protein mediated by NS, whereas it completely prevented that of Fpn. H-ferritin protein expression (Figure 6B) induced by NS was also blocked by the induction of SnPPIX, indicating that no iron was released from heme.

\section{DISCUSSION}

In this study, we used our cellular model to identify the respective roles of heme and iron in regulating the expression of Fpn during EP [21]. We demonstrate for the first time that in primary cultures of BMDM, heme derived from EP or from an exogenous source (such as Normosang( ${ }^{\circledR}$ can stimulate the transcription of the Fpn gene. Our kinetics of intracellular heme accumulation during EP indicate that heme is released from damaged erythrocytes engulfed by BMDM. The heme content then progressively decreases, probably reflecting its catabolism by HO1. Heme accumulation in BMDM appears to be greater following the phagocytosis of human erythrocytes than that of murine ones, which probably reflects interspecies differences in terms of erythrocyte size and hemoglobin content. However, the 
general profile of heme catabolism is similar in both species. It is noteworthy that changes in the intracellular heme content following EP in BMDM parallel the previously observed changes in HO1 and Fpn gene expression profiles [21], suggesting that heme itself could have a modulatory effect. We then describe several findings that demonstrate the early transcriptional up-regulation of the Fpn gene by heme in BMDM. First, heme-arginate or Normosang ${ }^{\circledR}$ used as an exogenous source of heme induced Fpn mRNA accumulation. Second, pre-treating the cells with actinomycin D (an inhibitor of RNA polymerase II) blocked the heme-mediated induction of Fpn and HO1 mRNAs. Finally, inhibiting HO1 activity by SnPPIX and/or intracellular chelation of iron partly prevented the accumulation of Fpn mRNA. Our observations after EP or heme treatment suggest that most of Fpn mRNAs levels are stimulated by heme and the remaining by the release of iron from heme. This transcriptional effect mediated by heme is consistent with the recent demonstration of hemoglobin-induced Fpn mRNA in haptoglobin-null spleen macrophages and in vitro in RAW264.7 macrophages [28].

Previous studies have shown that iron can increase the transcription of Fpn in macrophages $[14,22]$. We also observed that Fe-NTA triggered a slight increase in Fpn mRNA, whereas SIH reduced basal Fpn mRNA expression (data not shown). However, and this is consistent with our findings, iron chelation was shown to produce only partial inhibition of the increase in Fpn mRNAs in a different model of EP using J774 macrophages [14]. This suggests that heme-dependent transcriptional induction of this gene predominates after RBC phagocytosis, and that the iron released from heme is mildly involved in this regulation.

Heme is known to be a direct transcriptional inducer of the $\mathrm{HO} 1$ gene. Indeed, this gene has been shown to be transcriptionally regulated by heme in various types of cell, including hepatoma cells [29], rat glioma cells [30] and cultured alveolar macrophages [27]. Regulation of the HO1 gene involves the transportation of heme into the nucleus by a carrier and its binding to the physiological repressor Bach1, which allows transcriptional activators to initiate transcription $[31,32]$. Bach1 forms heterodimer with MafK and binds to the multiple Maf recognition elements (MAREs) of HO1 enhancers. Thereby Bach1 represses their activity in vivo, whereas heme interferes with this function of Bach1 by inhibiting its binding to the HOl enhancers [32]. It is tempting to speculate that similar regulatory mechanisms could be involved in the transcriptional regulation of Fpn by heme. Even though sequence analysis of the Fpn gene promoter did not reveal the presence of MAREs, possible direct transcriptional regulation of Fpn by heme cannot be ruled out. We have previously shown 
differences in the patterns of expression of the HO1 and Fpn genes in BMDMs during EP [21]. Indeed, we observed that 2 hours after EP, HO1 mRNA was already strongly induced whereas Fpn mRNA level was not changed. Later after EP, Fpn mRNA was strongly repressed whereas expression of $\mathrm{HOl}$ was maintained at a quite high level. These observations suggest that these two genes could be regulated by different mechanisms, both of which are mediated by heme. Various heme-regulated transcription factors may exist in mammalian cells [33] and further analysis is needed to identify the functional cis and trans regulatory elements involved in heme-mediated activation of Fpn transcription.

It is striking that our results indicate that an iron atom must be present in the protoporphyrin ring in order to observe the induction of Fpn and HO1 mRNAs. One can speculate that conformation changes induced by the presence of iron allow heme to interact with heme transporters or protein partners in order to mediate its transcriptional activity. We also noted that SnPPIX affects Fpn and HO1 mRNA in BMDM (Figure 6). SnPPIX acts as a competitive inhibitor of HO1, even though it also increases its expression [34]. This effect is probably linked to the similarities in chemistry and structure of this heme-analog, which could bind to the same regulatory sites as heme itself [34], and one can speculate that SnPPIX could induce HO1 and Fpn mRNA in a similar manner. This induction could also be the consequence of the potential increase in the cellular heme content, resulting from the inhibition of HO1 activity. Further investigation is needed to clarify this point.

Although the heme contained in erythrocytes or heme/Normosang® appears to be the main transcriptional inducer of the Fpn gene in BMDM, we demonstrate that the synthesis of the transporter at the protein level depends mainly on iron. In contrast, upregulation of $\mathrm{HO} 1$ protein by heme was shown to be iron-independent. Our data illustrate the absolute requirement for the catabolism of heme by $\mathrm{HO1}$, and the subsequent release of iron, to increase the level of the Fpn protein in BMDM. The observation that an iron chelator (SIH) or an inhibitor of HO1 activity (SnPPIX) suppresses EP or heme induction of Fpn at the protein level shows that iron extracted from heme by the catabolitic activity of HO1 is indeed responsible for up-regulating Fpn proteins. Like the mRNA that codes the iron storage protein H-ferritin, Fpn mRNA contains an IRE in its 5'UTR. Translation of proteins from mRNAs containing IREs in their 5'UTRs is known to be controlled by a mechanism involving the iron sensors IRPs [10]. Several observations suggest that there is a functional IRE in the 5'UTR of Fpn mRNA. First of all, IRPs can bind to Fpn IRE [8]. More importantly, when placed in front of a luciferase reporter gene, the Fpn IRE is able to control gene expression via an irondependent regulatory effect $[11,12]$. It is therefore likely that Fpn IRE confers translational 
control of the Fpn gene during EP. However one cannot exclude the possiblity that a posttranscriptional mechanism could exist that also affects mRNA stability.

In addition, even though most of the effect of heme stimulation on Fpn protein is mediated by iron, the increase in Fpn mRNA levels mediated by heme itself may also be critical in this induction. Indeed, by blocking transcription, the up-regulation of the Fpn protein by heme is completely abolished. It is therefore tempting to speculate that Fpn mRNA levels are low or unstable in the cells. A combination of these two regulatory pathways (the heme-mediated transcriptional induction followed by the iron-mediated post-transcriptional stimulation) is probably responsible for the marked increase in Fpn proteins following heme treatment in BMDM. We also show that similarly to iron treatment and EP [13], heme increases the Fpn distribution to the cell surface of BMDM. Such localisation of Fpn after NS treatment is consistent with a role of the exporter in the efflux of heme-derived iron.

By contrast to Fpn, the strong increase of ferritin protein after NS treatment is mildly decreased by the addition of actinomycinD. This indicates that H-ferritin induction by hemin is strongly related to post-transcriptional mechanisms as previously observed [35, 36]. In addition, our observation also suggests the existence of a transcriptional regulation of ferritin after heme treatment. Indeed, recently, heme was shown to regulate the transcription of $\mathrm{H}$ ferritin through the heme reversible repressor Bach1 [37].

In conclusion, we show that heme is a novel effector of Fpn gene regulation in macrophages. Such regulation reveals the existence of a balance between heme and iron in activating the expression of the Fpn gene in BMDM during the early stages of EP (Figure 7). We propose that during the process of EP or after heme treatment, heme may stimulate both HO1 and Fpn mRNAs (Step 1). The increased level of the HO1 protein then leads to heme catabolism and iron release (Step 2), which in turn stimulates the synthesis of Fpn at the transcription and, particularly at a post-transcription level (Step 3). Iron export driven by Fpn could then contribute to restore the baseline situation (Step 3). This regulation is of particular interest with regards to disorders such as hemolytic anemia. Both extra- and intra-vascular hemolysis lead to excessive heme absorption and iron accumulation in macrophages. During extravascular hemolysis, these observations are the consequence of an accelerated EP process in tissue macrophages. In a context of intravascular hemolysis, lysis of RBC in the circulation leads to an excess of hemoglobin and heme, which are rapidly bound to haptoglobin and hemopexin, respectively. Such complexes are then internalized by macrophages via receptormediated endocytosis [38-40]. Further characterisations of the dual heme/iron event 
involved in regulating the Fpn gene during EP will help to elucidate the molecular mechanisms involved in hemolytic processes.

\section{AKNOWLEDGMENTS}

The authors are grateful to Dr. Sophie Vaulont (Institut Cochin, Inserm 567, Paris France) and to Dr. Cécile Bouton (ICSN, CNRS, UPR 2301, Gif-Sur-Yvette, France) for helpful discussion and critical reading of the manuscript. We greatly appreciate the gift of Normosang ${ }^{\circledR}$ (NS) from Prof. Jean Charles Deybach (Centre Français des Porphyries, Hôpital Louis Mourier, Colombes, France). We also would like to express our thanks to Dr. Prem Ponka (Lady Davis Institute of Medical Research, Montreal, Canada) for the kind gift of SIH, and to P. Santambrogio and S. Levi (DIBIT San Raffaele Scientific Institute, Milano, Italy) for providing the anti-ferritin antibody. This study was financially supported by the Institut National de la Santé et de la Recherche (INSERM).

\section{FOOTNOTES}

The abbreviations used are: Fpn, ferroportin; HO1, heme oxygenase1; H-Ft, H ferritin; NS, Normosang®; BMDM, bone marrow derived macrophages; PPIX, protoporphyrin IX; SnPPIX, Tinprotoporphyrin; EP, erythrophagocytosis; RBC, red blood cells; hRBC, human red blood cells; IRE, iron responsive element; IRP, iron regulatory protein; UTR, untranslated region; SIH, salicylaldehyde isonicotinoyl hydrazone; Fe-NTA, iron-nitrilotriacetate; ActD, actinomycin D.

\section{REFERENCES}

1 Knutson, M. and Wessling-Resnick, M. (2003) Iron metabolism in the reticuloendothelial system. Crit. Rev. Biochem. Mol. Biol. 38, 61-88

2 Maines, M. D. (1997) The heme oxygenase system: a regulator of second messenger gases. Annu. Rev. Pharmacol. Toxicol. 37, 517-554

3 Poss, K. D. and Tonegawa, S. (1997) Heme oxygenase 1 is required for mammalian iron reutilization. Proc. Natl. Acad. Sci. U.S.A. 94, 10919-10924

4 Tenhunen, R., Marver, H. S. and Schmid, R. (1969) Microsomal heme oxygenase. Characterization of the enzyme. J. Biol. Chem. 244, 6388-6394

5 Richardson, D. R. and Ponka, P. (1997) The molecular mechanisms of the metabolism and transport of iron in normal and neoplastic cells. Biochim Biophys Acta 1331, 1-40

6 Abboud, S. and Haile, D. J. (2000) A novel mammalian iron-regulated protein involved in in tracellular iron metabolism. J. Biol. Chem. 275, 19906-19912

7 Donovan, A., Brownlie, A., Zhou, Y., Shepard, J., Pratt, S. J., Moynihan, J., Paw, B. H., Drejer, A., Barut, B., Zapata, A., Law, T. C., Brugnara, C., Lux, S. E., Pinkus, G. S., Pinkus, J. L., Kingsley, P. D., Palis, J., Fleming, M. D., Andrews, N. C. and Zon, L. I. (2000) Positional cloning of zebrafish ferroportin1 identifies a conserved vertebrate iron exporter. Nature 403, 776-781

8 McKie, A. T., Marciani, P., Rolfs, A., Brennan, K., Wehr, K., Barrow, D., Miret, S., Bomford, A., Peters, T. J., Farzaneh, F., Hediger, M. A., Hentze, M. W. and Simpson, 
R. J. (2000) A novel duodenal iron-regulated transporter, IREG1, implicated in the basolateral transfer of iron to the circulation. Mol. Cell. 5, 299-309

9 Canonne-Hergaux, F., Donovan, A., Delaby, C., Wang, H. J. and Gros, P. (2006) Comparative studies of duodenal and macrophage ferroportin proteins. Am. J. Physiol. Gastrointest. Liver. Physiol. 290, G156-163

10 Hentze, M. W. and Kuhn, L. C. (1996) Molecular control of vertebrate iron metabolism: mRNA-based regulatory circuits operated by iron, nitric oxide, and oxidative stress. Proc. Natl. Acad. Sci. U.S.A. 93, 8175-8182

11 Lymboussaki, A., Pignatti, E., Montosi, G., Garuti, C., Haile, D. J. and Pietrangelo, A. (2003) The role of the iron responsive element in the control of ferroportin1/IREG1/MTP1 gene expression. J. Hepatol. 39, 710-715

12 Liu, X. B., Hill, P. and Haile, D. J. (2002) Role of the ferroportin iron-responsive element in iron and nitric oxide dependent gene regulation. Blood Cells Mol. Dis. 29, 315-326

13 Delaby, C., Pilard, N., Goncalves, A. S., Beaumont, C. and Canonne-Hergaux, F. (2005) Presence of the iron exporter ferroportin at the plasma membrane of macrophages is enhanced by iron loading and down-regulated by hepcidin. Blood 106, 3979-3984

14 Knutson, M. D., Vafa, M. R., Haile, D. J. and Wessling-Resnick, M. (2003) Iron loading and erythrophagocytosis increase ferroportin 1 (FPN1) expression in J774 macrophages. Blood 102, 4191-4197

15 Ganz, T. (2005) Hepcidin-a regulator of intestinal iron absorption and iron recycling by macrophages. Best. Pract. Res. Clin. Haematol. 18, 171-182

16 Nicolas, G., Bennoun, M., Devaux, I., Beaumont, C., Grandchamp, B., Kahn, A. and Vaulont, S. (2001) Lack of hepcidin gene expression and severe tissue iron overload in upstream stimulatory factor 2 (USF2) knockout mice. Proc. Natl. Acad. Sci. U.S.A. 98, 8780-8785

17 Pigeon, C., Ilyin, G., Courselaud, B., Leroyer, P., Turlin, B., Brissot, P. and Loreal, O. (2001) A new mouse liver-specific gene, encoding a protein homologous to human antimicrobial peptide hepcidin, is overexpressed during iron overload. J. Biol. Chem. 276, 7811-7819

18 Nemeth, E., Tuttle, M. S., Powelson, J., Vaughn, M. B., Donovan, A., Ward, D. M., Ganz, T. and Kaplan, J. (2004) Hepcidin regulates cellular iron efflux by binding to ferroportin and inducing its internalization. Science 306, 2090-2093

19 De Domenico, I., Ward, D. M., Nemeth, E., Vaughn, M. B., Musci, G., Ganz, T. and Kaplan, J. (2005) The molecular basis of ferroportin-linked hemochromatosis. Proc. Natl. Acad. Sci. U.S.A. 102, 8955-8960

20 Knutson, M. D., Oukka, M., Koss, L. M., Aydemir, F. and Wessling-Resnick, M. (2005) Iron release from macrophages after erythrophagocytosis is up-regulated by ferroportin 1 overexpression and down-regulated by hepcidin. Proc. Natl. Acad. Sci. U.S.A. 102, 1324-1328

21 Delaby, C., Pilard, N., Hetet, G., Driss, F., Grandchamp, B., Beaumont, C. and Canonne-Hergaux, F. (2005) A physiological model to study iron recycling in macrophages. Exp. Cell. Res. 310, 43-53

22 Yang, F., Wang, X., Haile, D. J., Piantadosi, C. A. and Ghio, A. J. (2002) Iron increases expression of iron-export protein MTP1 in lung cells. Am. J. Physiol. Lung Cell. Mol. Physiol. 283, L932-939

23 Motterlini, R., Foresti, R., Vandegriff, K., Intaglietta, M. and Winslow, R. M. (1995) Oxidative-stress response in vascular endothelial cells exposed to acellular hemoglobin solutions. Am. J. Physiol. 269, H648-655 
24 Goncalves, A. S., Muzeau, F., Blaybel, R., Hetet, G., Driss, F., Delaby, C., CanonneHergaux, F. and Beaumont, C. (2006) Wild-type and mutant ferroportins do not form oligomers in transfected cells. Biochem. J. 396, 265-275

25 Viatte, L., Lesbordes-Brion, J. C., Lou, D. Q., Bennoun, M., Nicolas, G., Kahn, A., Canonne-Hergaux, F. and Vaulont, S. (2005) Deregulation of proteins involved in iron metabolism in hepcidin-deficient mice. Blood 105, 4861-4864

26 Lang, K. S., Lang, P. A., Bauer, C., Duranton, C., Wieder, T., Huber, S. M. and Lang, F. (2005) Mechanisms of suicidal erythrocyte death. Cell. Physiol. Biochem. 15, 195202

27 Shibahara, S., Yoshida, T. and Kikuchi, G. (1979) Mechanism of increase of heme oxygenase activity induced by hemin in cultured pig alveolar macrophages. Arch. Biochem. Biophys. 197, 607-617

28 Fagoonee, S., Gburek, J., Hirsch, E., Marro, S., Moestrup, S. K., Laurberg, J. M., Christensen, E. I., Silengo, L., Altruda, F. and Tolosano, E. (2005) Plasma protein haptoglobin modulates renal iron loading. Am. J. Pathol. 166, 973-983

29 Alam, J. and Smith, A. (1989) Receptor-mediated transport of heme by hemopexin regulates gene expression in mammalian cells. J. Biol. Chem. 264, 17637-17640

30 Shibahara, S., Muller, R. M. and Taguchi, H. (1987) Transcriptional control of rat heme oxygenase by heat shock. J. Biol. Chem. 262, 12889-12892

31 Sun, J., Brand, M., Zenke, Y., Tashiro, S., Groudine, M. and Igarashi, K. (2004) Heme regulates the dynamic exchange of Bach1 and NF-E2-related factors in the Maf transcription factor network. Proc. Natl. Acad. Sci. U.S.A. 101, 1461-1466

32 Sun, J., Hoshino, H., Takaku, K., Nakajima, O., Muto, A., Suzuki, H., Tashiro, S., Takahashi, S., Shibahara, S., Alam, J., Taketo, M. M., Yamamoto, M. and Igarashi, K. (2002) Hemoprotein Bach1 regulates enhancer availability of heme oxygenase-1 gene. EMBO J. 21, 5216-5224

33 Mense, S. M. and Zhang, L. (2006) Heme: a versatile signaling molecule controlling the activities of diverse regulators ranging from transcription factors to MAP kinases. Cell. Res. 16, 681-692

34 Smith, A., Alam, J., Escriba, P. V. and Morgan, W. T. (1993) Regulation of heme oxygenase and metallothionein gene expression by the heme analogs, cobalt-, and tinprotoporphyrin. J. Biol. Chem. 268, 7365-7371

35 Eisenstein, R. S., Garcia-Mayol, D., Pettingell, W. and Munro, H. N. (1991) Regulation of ferritin and heme oxygenase synthesis in rat fibroblasts by different forms of iron. Proc. Natl. Acad. Sci. U.S.A. 88, 688-692

36 Sheftel, A. D., Kim, S. F. and Ponka, P. (2007) Non-heme induction of heme oxygenase-1 does not alter cellular iron metabolism. J. Biol. Chem. 282, 10480-10486

37 Hintze, K. J., Katoh, Y., Igarashi, K. and Theil, E. C. (2007) Bach1 Repression of Ferritin and Thioredoxin Reductase 1 Is Heme-sensitive in Cells and in Vitro and Coordinates Expression with Heme Oxygenase1, beta-Globin, and NADP(H) Quinone (Oxido) Reductase1. J. Biol. Chem. 282, 34365-34371

38 Hvidberg, V., Maniecki, M. B., Jacobsen, C., Hojrup, P., Moller, H. J. and Moestrup, S. K. (2005) Identification of the receptor scavenging hemopexin-heme complexes. Blood 106, 2572-2579

39 Schaer, D. J., Schaer, C. A., Buehler, P. W., Boykins, R. A., Schoedon, G., Alayash, A. I. and Schaffner, A. (2006) CD163 is the macrophage scavenger receptor for native and chemically modified hemoglobins in the absence of haptoglobin. Blood 107, 373380 
40 Kristiansen, M., Graversen, J. H., Jacobsen, C., Sonne, O., Hoffman, H. J., Law, S. K. and Moestrup, S. K. (2001) Identification of the haemoglobin scavenger receptor. Nature 409, 198-201

\section{FIGURE LEGENDS}

Figure 1: Upregulation of Fpn and HO1 mRNAs after phagocytosis of human red blood cells. (A) BMDM were incubated with $1 \times 10^{7}, 2 \times 10^{7}$ or $3 \times 10^{7}$ artificially aged human red blood cells (hRBC) per ml of culture medium for one hour. Non-ingested hRBC were lysed and removed, and the incubation continued for another 3 hours. In (B) the erythrophagocytosis assay with hRBC was performed in the presence or absence of the iron chelator SIH.

Figure 2: Heme is rapidly degraded following phagocytosis of RBC by macrophages. BMDM were incubated with murine (A) or human (B) aged erythrocytes for 50 minutes $(50 \%)$. Any non-ingested RBC were lysed and removed, and the incubation continued for the periods of time indicated. The cells were then lysed in formic acid, and the intracellular heme concentration was determined spectrophotometrically at $400 \mathrm{~nm}$. Results represent the OD measured per million of macrophages and normalized to control values.

Figure 3: Effect of heme on the expression of Fpn and HO1 mRNAs. (A) BMDM were incubated with $10 \mu \mathrm{M}$ or $50 \mu \mathrm{M}$ Normosang® (NS). After $90 \mathrm{~min}$, the intracellular heme concentration was determined $\left(\mathrm{OD}_{400 \mathrm{~nm}} / 10^{6}\right.$ macrophages normalized to control values: fold induction; upper panel). Fpn and HO1 mRNAs were quantified by RT-PCR after 4 hours of NS treatment. In (B), macrophages were treated with either hemin-arginate $(10 \mu \mathrm{M})$ or PPIXarginate $(10 \mu \mathrm{M})$ for 4 hours before being subjected to RNA extraction and quantitative RTPCR of Fpn and HO1. (*: p-yalues $\leq 0.005)$.

Figure 4: Contribution of iron to the induction by heme of Fpn and HOI mRNAs and proteins. (A) Fpn and HO1 mRNAs were quantified by RT-PCR in BMDM treated with NS for 4 hours in the absence or in the presence of SIH (*: p-values $\leq 0.005)$. (B) Fpn protein was detected by immunofluorescence in untreated macrophages or macrophages treated for 8 hours with Fe-NTA $(100 \mu \mathrm{M})$ PPIX-arginate $(10 \mu \mathrm{M})$, heme arginate $(10 \mu \mathrm{M})$ or Normosang ${ }^{\circledR}(\mathrm{NS} ; 50 \mu \mathrm{M})$. For the negative control, the primary anti-Fpn antibody was omitted during immunofluorescence procedure [Control (-)]. (C) Western analysis of Fpn, 
$\mathrm{HO} 1$ and $\mathrm{H}-$ ferritin $(\mathrm{H}-\mathrm{Ft})$ in membrane (Fpn and HO1) or cytosol (H-Ft) extracts isolated from untreated murine macrophages (control) or murine macrophages treated with NS with or without SIH. ß-actin detection in membrane $(\mathrm{mb})$ and cytosolic (ct) extracts are shown as loading controls. The position and sizes (kilodaltons) of molecular mass markers are indicated on the right.

Figure 5: Heme stimulates the transcription of the Fpn and HOl genes.(A-B) BMDM were incubated for 4 hours (A) or 8 hours (B) with $10 \mu \mathrm{M}$ Normosang $(\mathrm{NS})$, with or without actinomycin D (ActD; $1 \mu \mathrm{g} / \mathrm{mL}$ ), before RNA (A) or protein (B) extractions, respectively. (A) Expression of Fpn and HO1 mRNA was evaluated by quantitative PCR (*: p-values $\leq 0.005)$. (B) Expression of the FpnHO1 and $\mathrm{H}$-ferritin (H-ft) proteins was analysed by Western-blot. $ß-$ actin detection is shown as loading control for both the membrane preparation (mb) and the cytosolic $(\mathrm{Ct})$ samples. The position and sizes (kilodaltons) of molecular mass markers are indicated on the right.

Figure 6: Iron release from heme by HOl activity is necessary for the induction of Fpn protein. (A-B) BMDM were pretreated with $50 \mu \mathrm{M}$ SnPPIX for 2 hours before adding $10 \mu \mathrm{M}$ Normosang ${ }^{\circledR}(\mathrm{NS})$ and $50 \mu \mathrm{M}$ SIH. Cells were then incubated for 2 hours (A) or 6 hours (B) before being subjected to RNA and protein extraction, respectively. (A) Expression of Fpn and HO1 mRNAs was evaluated by quantitative PCR. (B): Expression of Fpn, HO1 and Hferritin $(\mathrm{H}-\mathrm{ft})$ proteins was analysed by western-blot. $\beta$-actin detection is shown as loading control for both membrane preparation $(\mathrm{mb})$ and cytosolic $(\mathrm{Ct})$ samples. The position and sizes (kilodaltons) of molecular mass markers are indicated on the right.

Figure 7: Sequential regulation of Fpn expression in BMDM after EP: early mRNA induction by heme followed by iron-dependent protein expression. Following treatment (EP or Heme/Normosang( $($ ), the intracellular heme content increased in BMDM and induced transcription of both the HOl and Fpn genes (Step 1). The HO1 protein translated then catabolised heme, leading to a fall in heme content and the release of iron into the cytosol (Step 2). Iron has a slight effect on Fpn transcription (dashed arrow). On the other hand, strong post-transcriptional regulation (probably translational) of Fpn mRNAs by iron induces synthesis of the Fpn protein (Step 3), which in turn drives the export of iron from BMDM, thus leading to a reduction of the cell iron content (Step 4). 


\section{Figure 1}

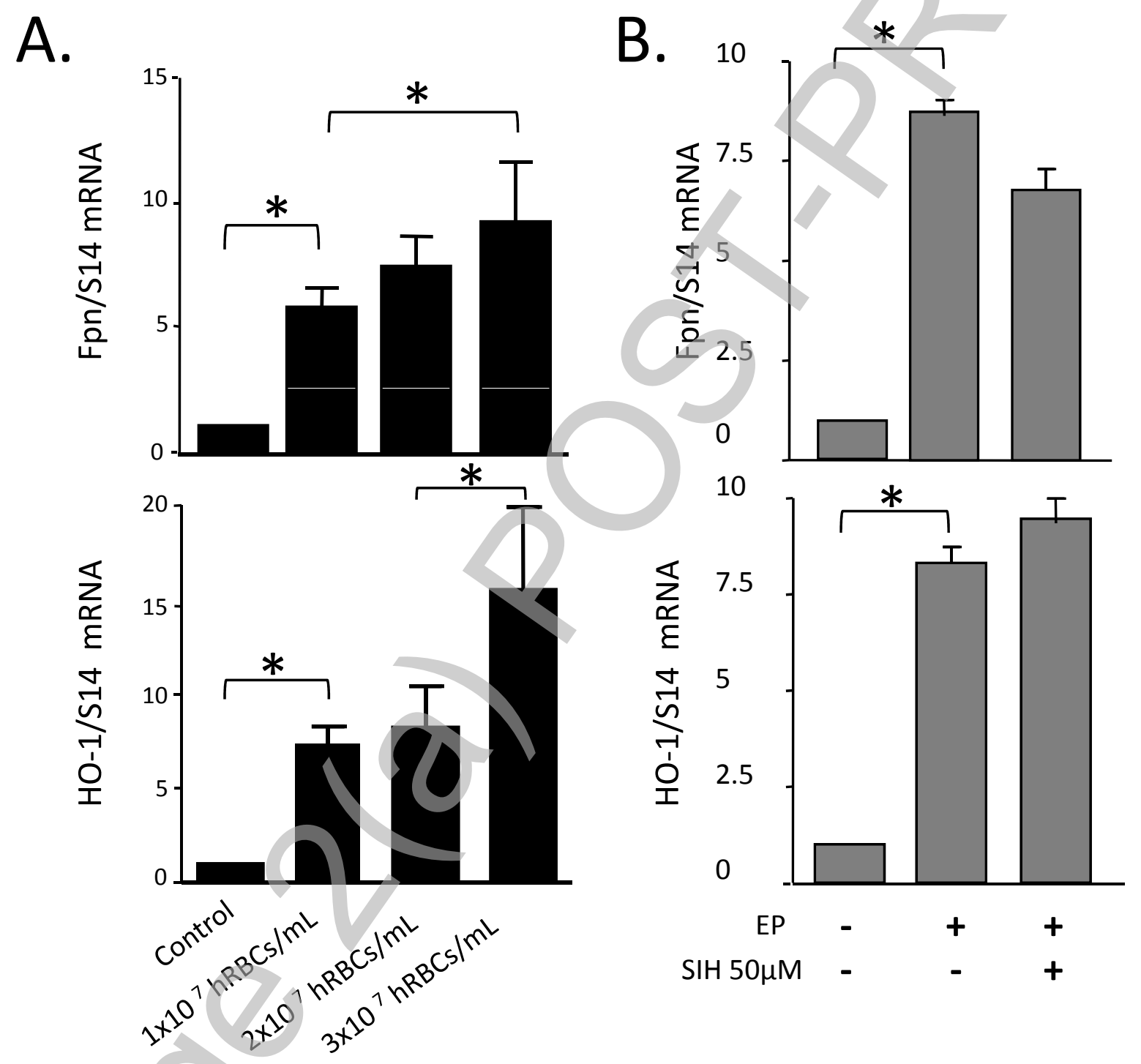


Figure 2

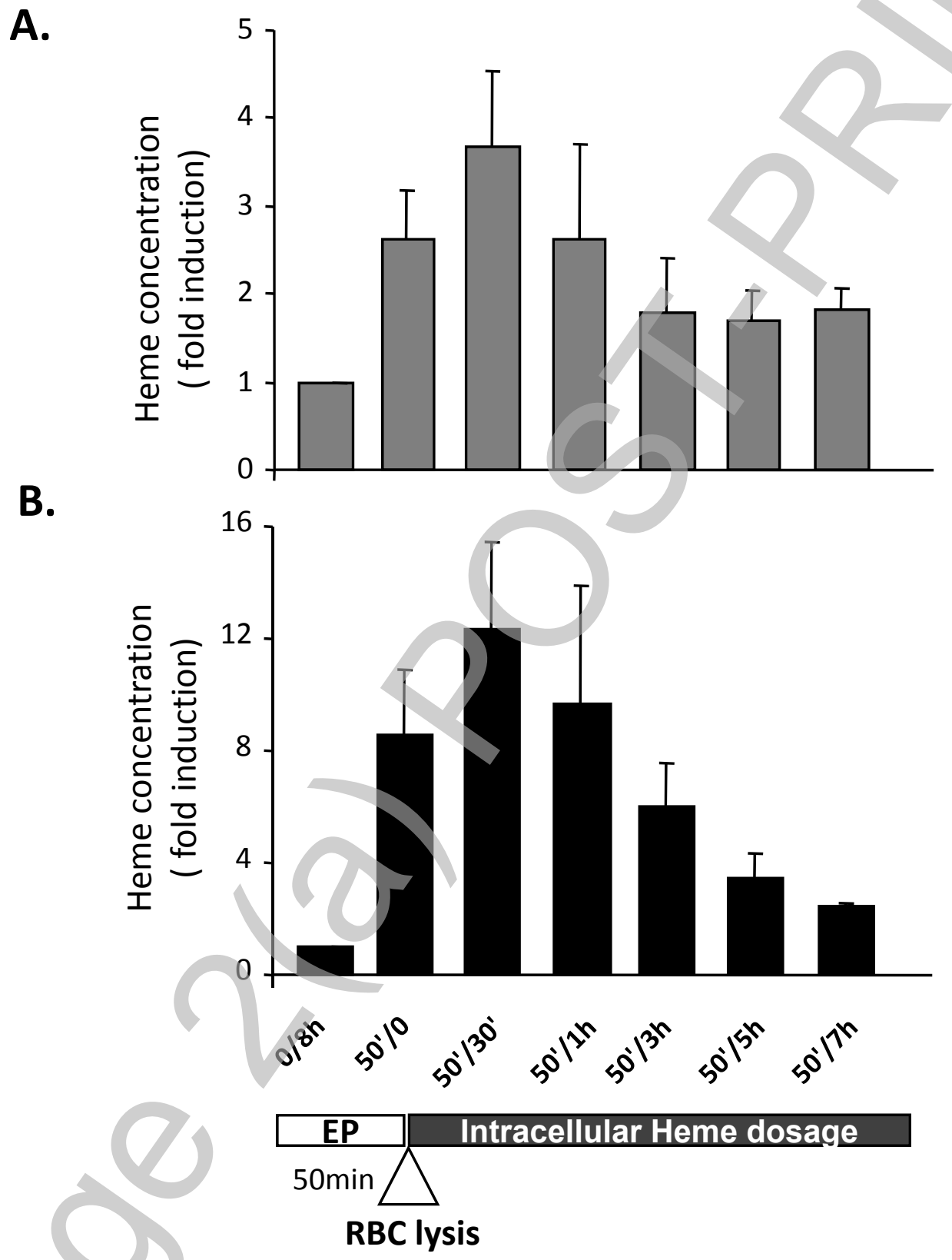


Figure 3

A.
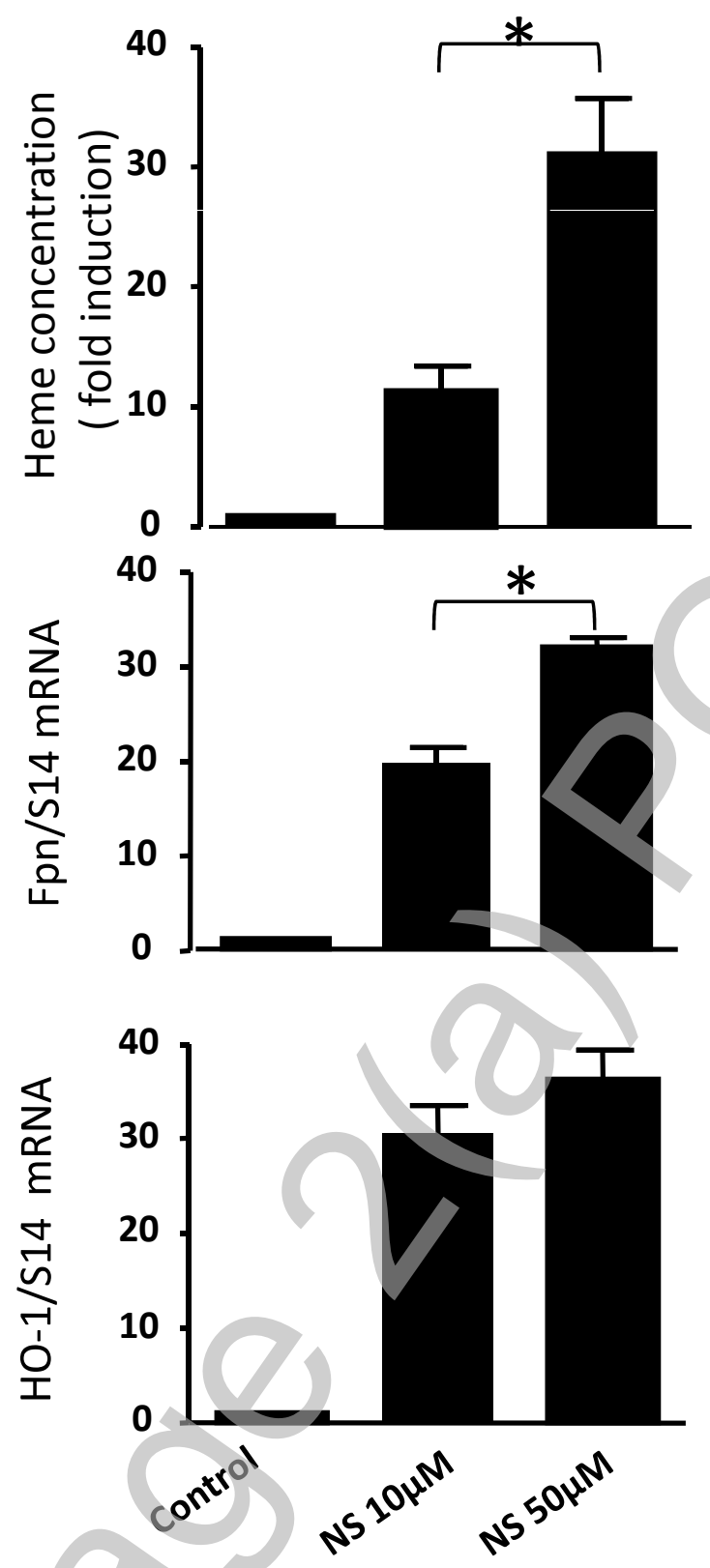

B.
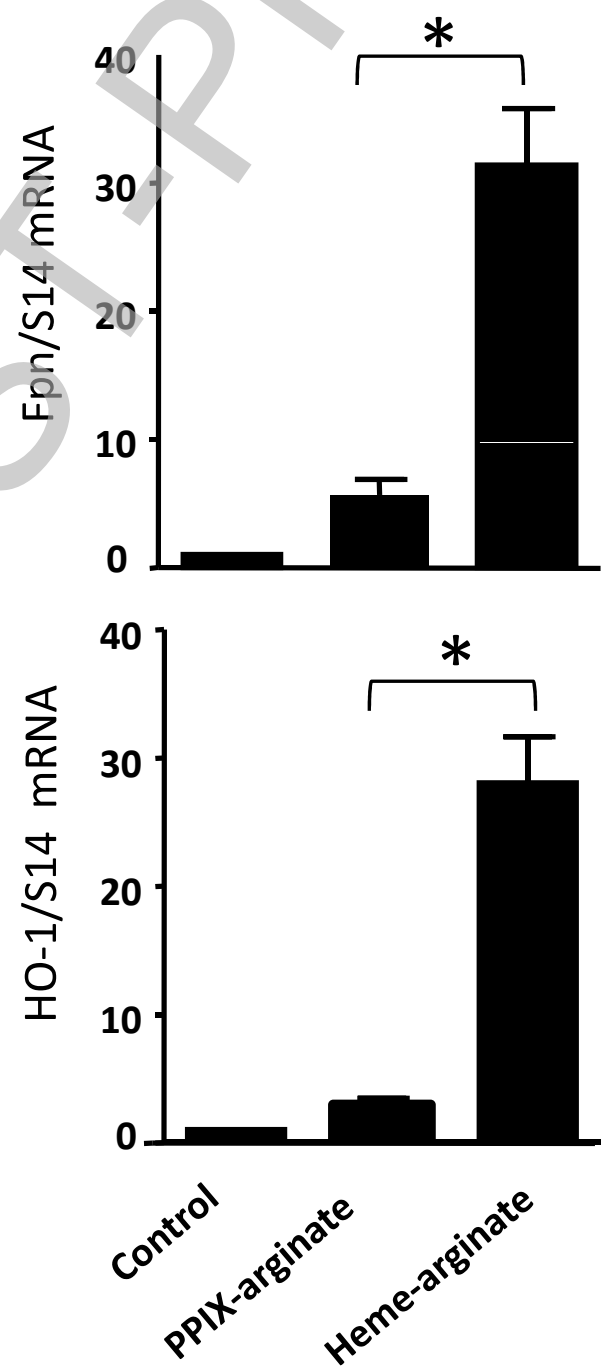


\section{Figure 4}

A.
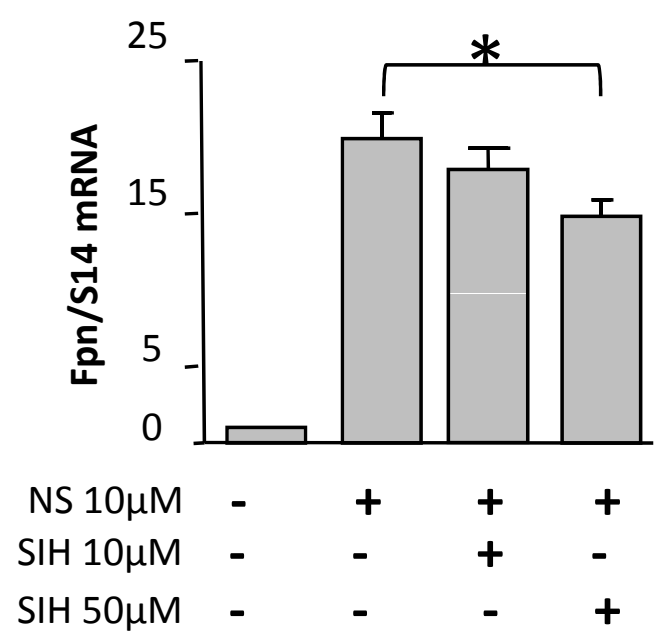

B.
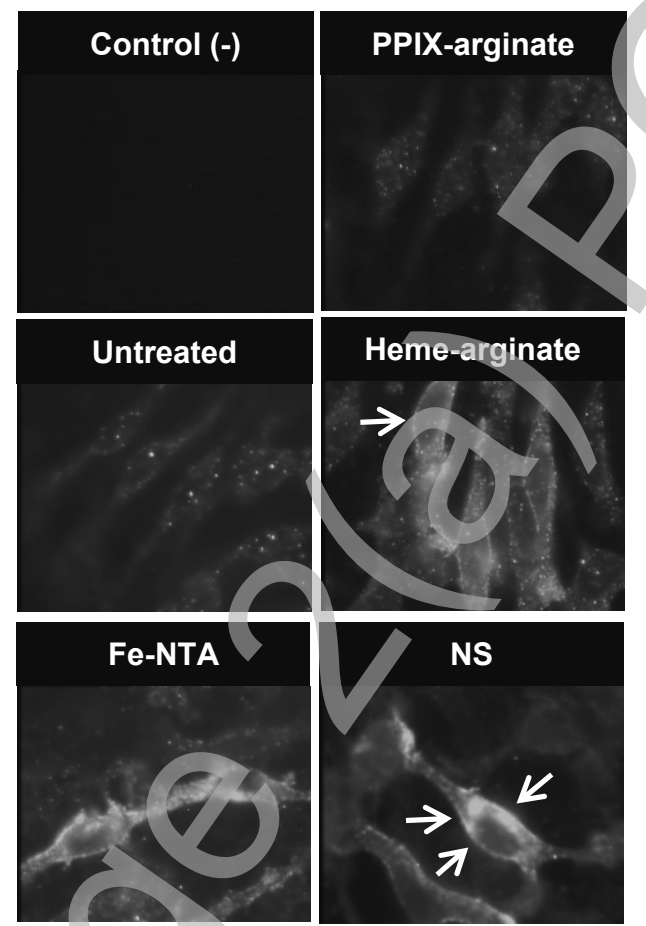


\section{Figure 5}

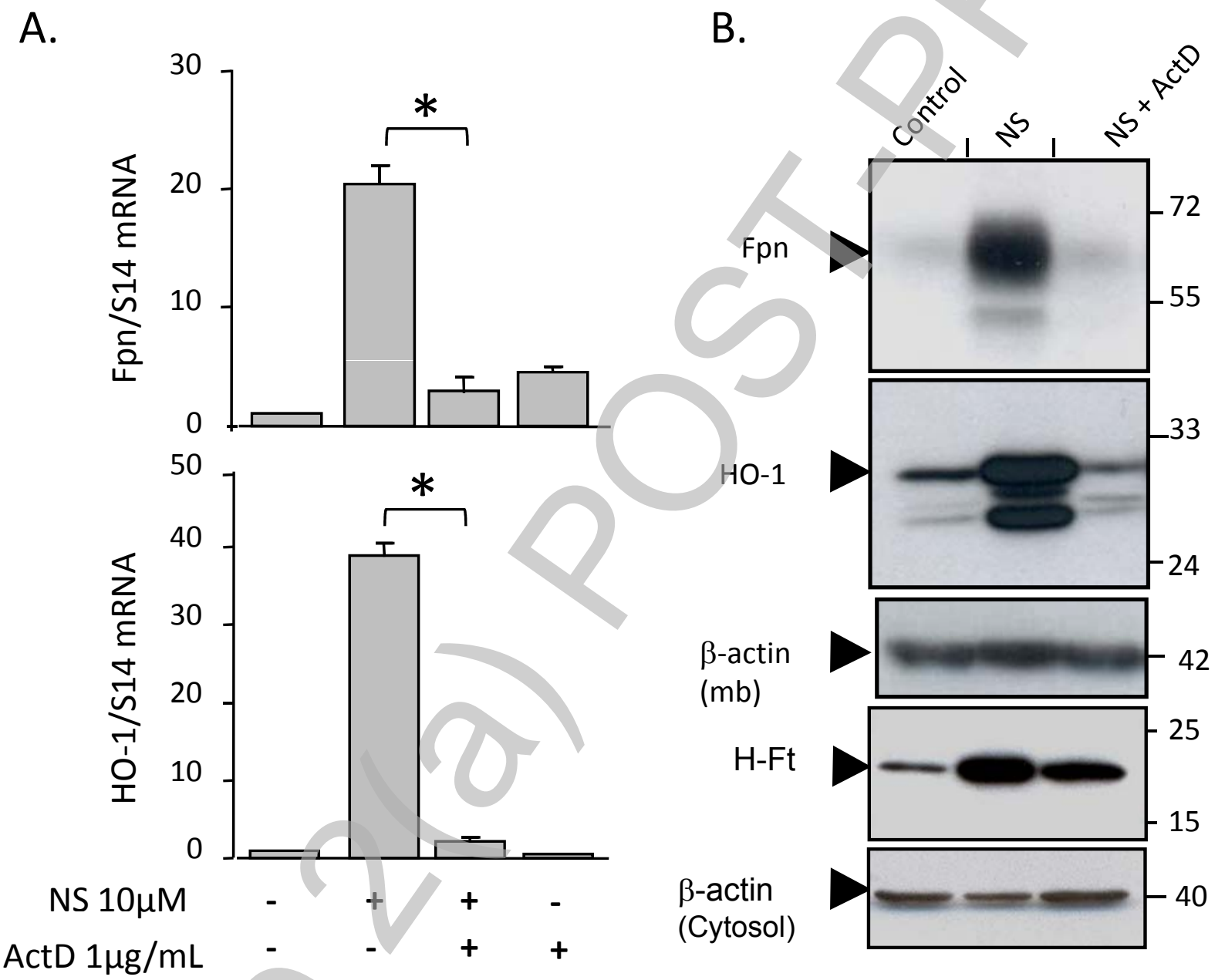




\section{Figure 6}

A.
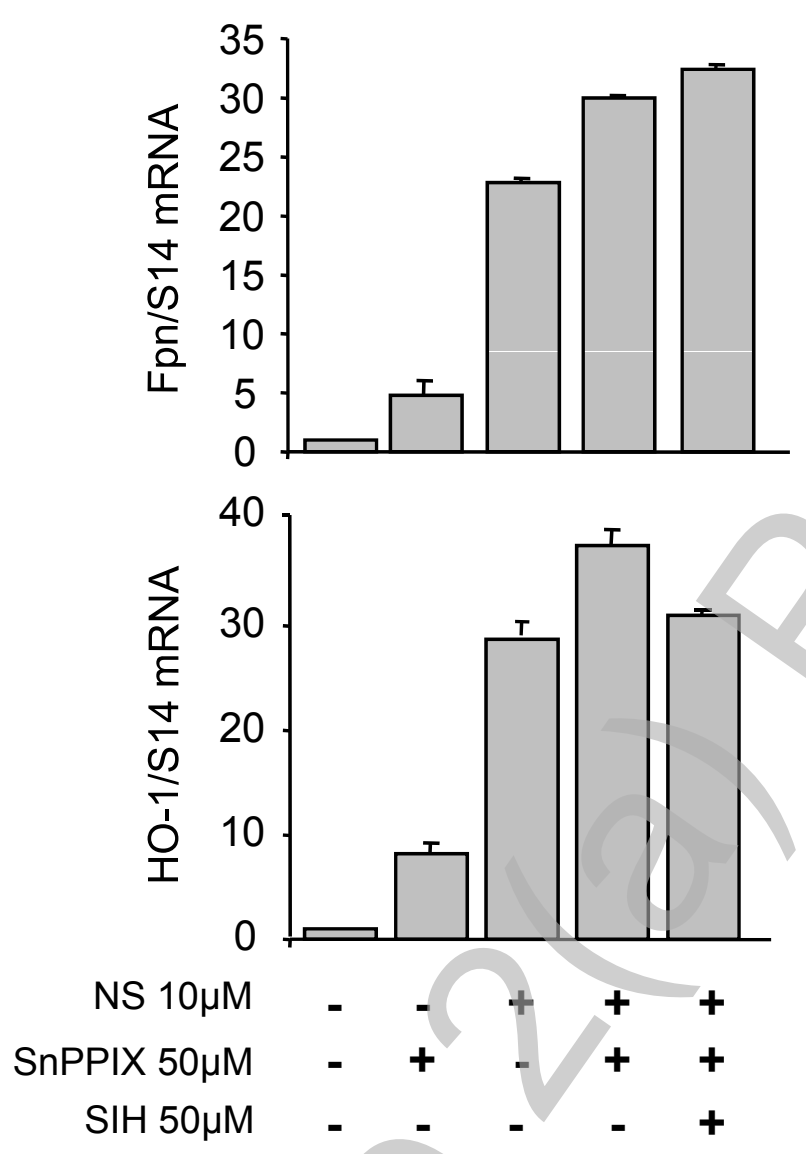

B.

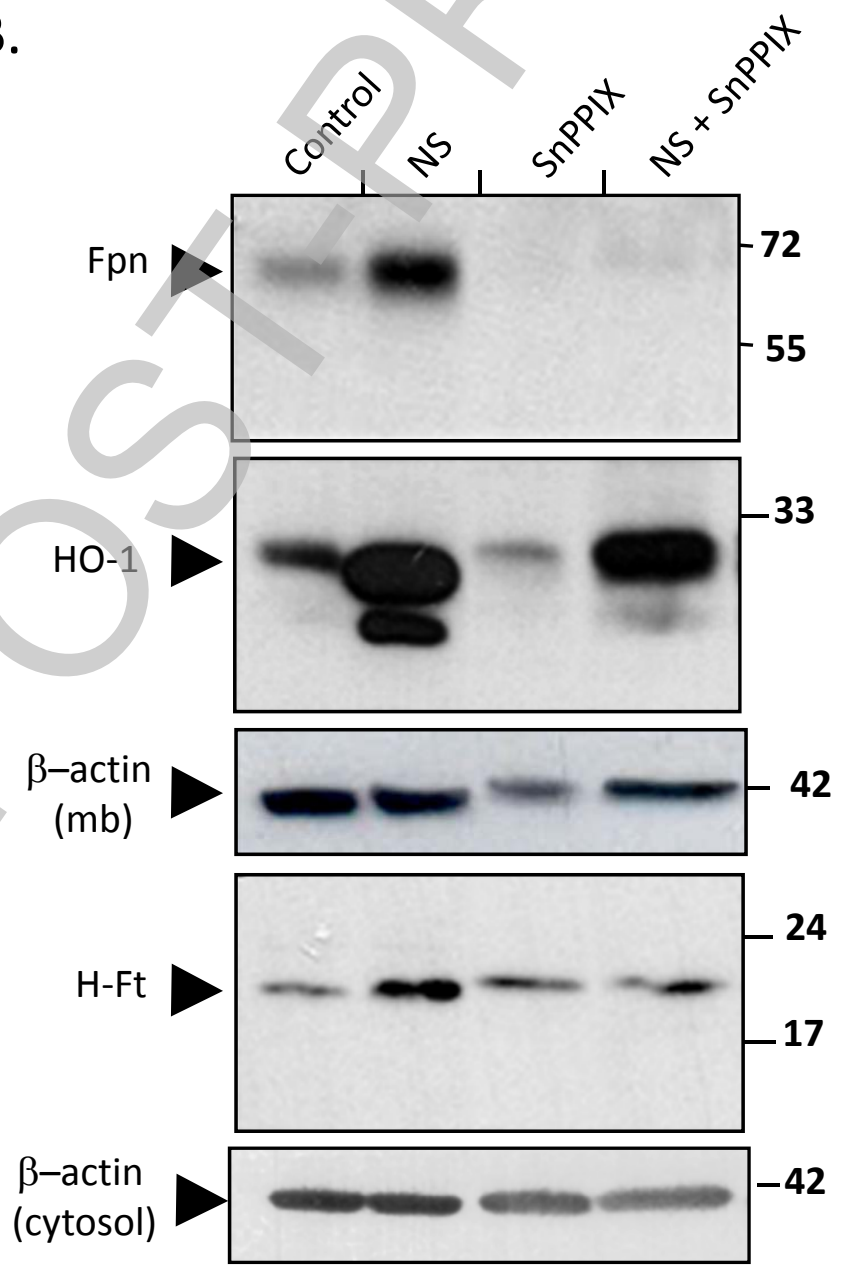




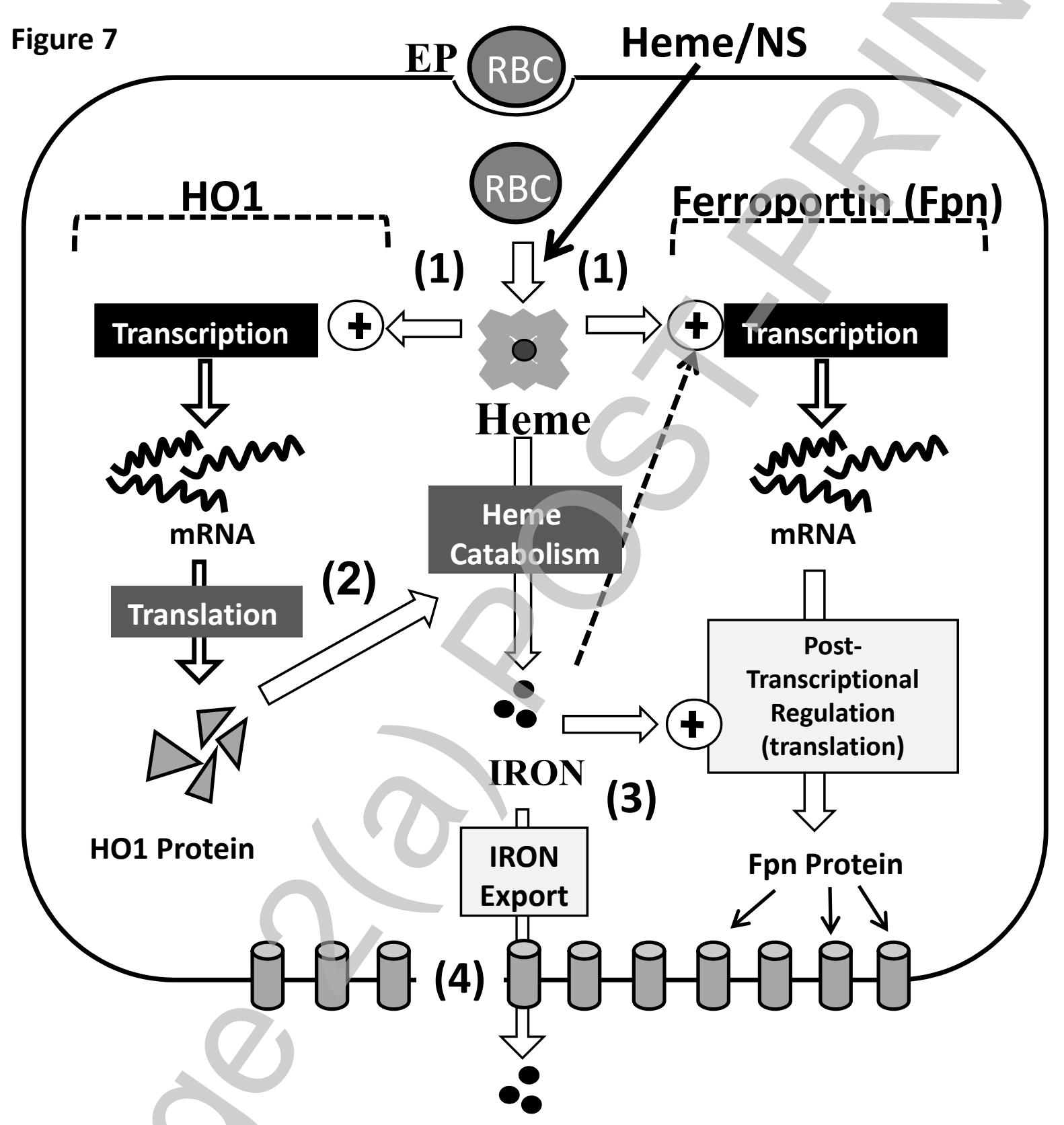

